\title{
Shrimp aquaculture as a vehicle for Climate Compatible Development in Sri Lanka.
}

\section{The case of Puttalam Lagoon.}

I.H.T. Harkes ${ }^{1}$, Asbjørn Drengstig ${ }^{2}$, M.P. Kumara ${ }^{3}$, J.M.P.K. Jayasinghe ${ }^{4}$, M. Huxham ${ }^{1}$

\begin{abstract}
${ }^{1}$ Edinburgh Napier University, Sighthill Court, Room 2B22, Edinburgh, EH11 4BN, United Kingdom. Tel: +44 (0)131 4552514; E-mail: m.huxham@napier.ac.uk (corresponding author)*

${ }^{2}$ Aqvisor AS, P.O. box 391, 4067 Stavanger, Norway. Tel: +47 90196731; E-mail: asbjorn@aqvisor.no

${ }^{3}$ Ocean University of Sri Lanka, Mahawela Road, Tangalle, Sri Lanka. Tel: +94 (0)71 6035682; E-mail: kumarampp@yahoo.com
\end{abstract}

${ }^{4}$ Wayamba University of Sri Lanka, Makandura, Gonawila, Sri Lanka. E-mail: jmpkjaya@gmail.com

\begin{abstract}
At present, aquaculture of black tiger shrimp (Penaeus monodon) in the Puttalam district of Sri Lanka is unsustainable with more than $90 \%$ of the former shrimp ponds laying abandoned as a result of shrimp disease and improper management. Between 1992-1998, over 50\% of the mangrove cover was removed in order to establish shrimp aquaculture. This severely affected the functioning of coastal ecosystems, reducing their provision of useful services and increasing coastal vulnerability to climate change. Changes in the hydrology and polluted residual matter make the soil unsuitable for other agricultural purposes without costly restoration. The root of the problem was inappropriate management and a focus on short term economic gains. Despite this previous failure, the national development plan, Mahinda Chinthana, now promotes aquaculture as an avenue for development. This will only be possible if aquaculture is regulated in a sustainable and well-managed manner, and does not increase local vulnerability to climate change effects.

The current paper discusses the possible costs and benefits in applying the concept of Climate Compatible Development (CCD) to shrimp aquaculture in Puttalam, Sri Lanka. It suggests how the sector can support mitigation of Green House Gas (GHG) emissions and adaptation to climate change effects, whilst stimulating development that will also benefit rural societies. Mechanisms that could enable this change include subsidies, insurance and bank loans which will also facilitate investment by foreign private enterprises and subsequent export. The development of a specific aquaculture policy and master plan would facilitate the process further.
\end{abstract}

\section{Keywords}

Shrimp aquaculture, Climate Compatible Development, Mitigation, Adaptation, Puttalam Lagoon, Sri Lanka.

*Present address: WWF-NL, Postbus 7, 3700 AA, Zeist, the Netherlands, Tel: +31(0)612556767; e-mail: iharkes@wwf.nl. 


\section{Shrimp aquaculture as a vehicle for Climate Compatible Development in Sri Lanka.}

\section{The case of Puttalam Lagoon.}

\section{Introduction}

Shrimp farming was introduced to Sri Lanka in 1985. By the early 90s the industry was booming with production rates of up to $9000 \mathrm{~kg} / \mathrm{ha} /$ year (Drengstig 2013a). High export volumes contributed significantly (48\%-70\%) to the total foreign exchange earnings during this period (Jayasinghe et al. 1994). However, in 1996 the first outbreak of the White Spot Syndrome Virus (WSSV) dealt a heavy blow to many farmers (Drengstig 2001). The industry revived, but a second disease outbreak in 1998 caused severe economic losses to all shrimp farmers in Sri Lanka. The final and most devastating outbreak came in 2004 and caused a permanent reduction in the productivity of the industry (Munasinghe et al. 2010; Drengstig et al. 2005). Production reduced to under $4000 \mathrm{~kg} / \mathrm{ha} / \mathrm{year}$ (Jayasinghe pers. comm.) and export of shrimps in 2012 (volume and value) dropped by more than $65 \%$ compared to 1999 (NAQDA 2012). Currently, an estimated $90 \%$ of the shrimp farms are abandoned (Bournazel et al. 2015), leaving the coast dotted with areas that are unsuitable for other forms of agricultural/aquaculture production, mainly due to changes in the hydrology and polluted residual matter (Munasinghe 2010).

The environmental costs that accompanied the establishment of shrimp farming in Sri Lanka are significant (Gunawardena and Rowan 2005). For the establishment of shrimp farms in Puttalam District, over $50 \%$ of healthy mangrove forest in the area was removed (Dahdouh-Guebas et al. 2002). With the loss of mangroves, an important buffer zone and habitat for marine life has disappeared (Danielsen et al. 2005; Alongi 2008). The construction of shrimp farms also led to the removal of above and below ground carbon, along with the potential for future carbon sequestration (Twilley et al. 1992; Donato et al. 2011, Bournazel et al. 2015). Other impacts include pollution of surface and ground water, in addition to the depletion of wild stocks and healthy broodstocks for coastal fisheries (Eng et al. 1989; De Silva and Jayasinghe 1993; Senarath and Visvanathan 2001; Dahdouh-Guebas et al. 2002, Mumby et al. 2004, GESAMP 2008; WWF 2014). As a result, rather than providing permanent economic benefits, the establishment of shrimp farms has led to unstable livelihoods and has increased the vulnerability of coastal populations to climate change impacts (Dayaratne et al. 1995; Cattermoul and Devendra 2002).

The Climate Change Vulnerability Data Book, published by the Ministry of Environment of Sri Lanka in 2011, acknowledges the high vulnerability of shrimp aquaculture farms to climate change effects, particularly in Puttalam District. Changes in rain patterns and increasing temperatures are already being observed by shrimp farmers and other stakeholders (Tejedor 2013). Rapid changes in temperature, salinity and oxygen can pose a shock to the immune system of shrimp triggering disease (particularly White Spot Syndrome Virus) to become active (Vargas-Albores et al. 1998; Direkbasurakom and Danayodol 1998; Tendencia and Verreth 2010; Ruiz-Velazco et al. 2010). As climate related stressors increase, the risk of disease outbreaks becomes larger and there is very little prospect of maintaining or increasing the current area or levels of production. To address 
climate change adaptation and increase the resilience of shrimp farming to these changes, a fundamentally different approach to shrimp farming is required.

The current study investigates the potential for a new future for shrimp aquaculture in Puttalam Lagoon, in the light of these challenges, as a vehicle for Climate Compatible Development (CCD). CCD is a policy framework that aims to identify those actions that could enhance adaptation to current and anticipated climate change impacts, whilst also mitigating the production of greenhouse gases and leading to increases in human welfare (Mitchell and Maxwell, 2010). It represents an attempt to learn from past mistakes and ensure that consideration of likely impacts of climate change is embedded in current planning. It also emphasises a broad definition of development, one that endorses human welfare rather than economic growth. The sorry legacy of intensive shrimp farming in Puttalam combines enhanced greenhouse gas production, loss of natural carbon sinks, increased vulnerability of coastal populations to anticipated climate impacts and economic benefits to a wealthy elite with costs borne by the local poor; a veritable case study in the opposite of CCD. Hence most alternative futures will be preferable to the status quo, but fully transforming this damaging industry provides a particularly challenging (and therefore useful) test of the CCD concept. Here, we consider which financial, technical and regulatory mechanisms are required as at least a start towards the application of CCD in the shrimp farming industry.

\section{Methodological approach}

The current functioning of shrimp farming in the Puttalam Lagoon was assessed through a sector analysis and literature review. To identify the current activity levels of shrimp farms, their typical mode of operation and management practices, an initial qualitative research project was conducted involving interviews with a range of local stakeholders (Tejedor 2013). In addition, changes in land use patterns and mangrove cover were identified by means of high resolution satellite imagery of Puttalam Lagoon in 1997 and 2007 and SPOT images in 2012 provided by Planet Action (Bournazel et al. 2015) The information was processed and uploaded onto an interactive web-based mapping tool Our Ecosystem that has been developed as part of this research project. ${ }^{1}$ The tool can be used in the decision-making process.

A visioning exercise was performed to develop a 'Business as Usual' (BAU) scenario as well as a future scenario where shrimp farming would be in line with CCD (Nap et al. submitted). During an expert meeting held in Colombo in December 2013, attended by representatives from relevant NGOs, government departments and academia, international sustainability standards (WWF 2011) and their applicability for shrimp farming in Puttalam Lagoon were discussed. To reach these standards and support the objectives of CCD, a set of technical interventions was identified as well as a number of Best Management Practices and mechanisms required to make the shift. A policy workshop served to identify the policy framework that would support CCD aquaculture in Sri Lanka. This information was collectively synthesised and resulted in the proposed course of action presented in this article.

\footnotetext{
${ }^{1}$ Our Ecosystem is an interactive web-based tool developed by Ecometrica and one of the outputs of the iCOAST project (www.icoast.our-ecosystem.com).It is available for policy makers and other stakeholders.
} 


\section{Setting the scene}

\subsection{Sri Lanka}

Sri Lanka has a total surface area of $65,610 \mathrm{~km}^{2}$ with a coastline of around $1,338 \mathrm{~km}$ length (Silva et al. 2013). With some 121,000 ha of lagoons and estuaries, it presents perfect opportunities for aquaculture (Drengstig 2013a).

In 2009, the 26-year conflict with the Liberation Tigers of Tamil Eelam ended, internally displaced persons were resettled and Sri Lanka improved its macro-economic situation. It is now a middleincome country with an average monthly household income of US\$280 (Statistics Unit, Chief Secretary's Office $\left.{ }^{2}\right)$. Sri Lanka has a total population of 20.2 million people with a literacy rate of $95 \%$ (Census of Population and Housing 2012). The poverty headcount index 2009/10 for Sri Lanka is 8.9\% (Statistics Unit, Chief Secretary's Office). The contribution of fisheries and aquaculture to the GDP is $1.7 \%$. Aquaculture and related activities directly and indirectly benefit over a million people (Galappaththi 2013).

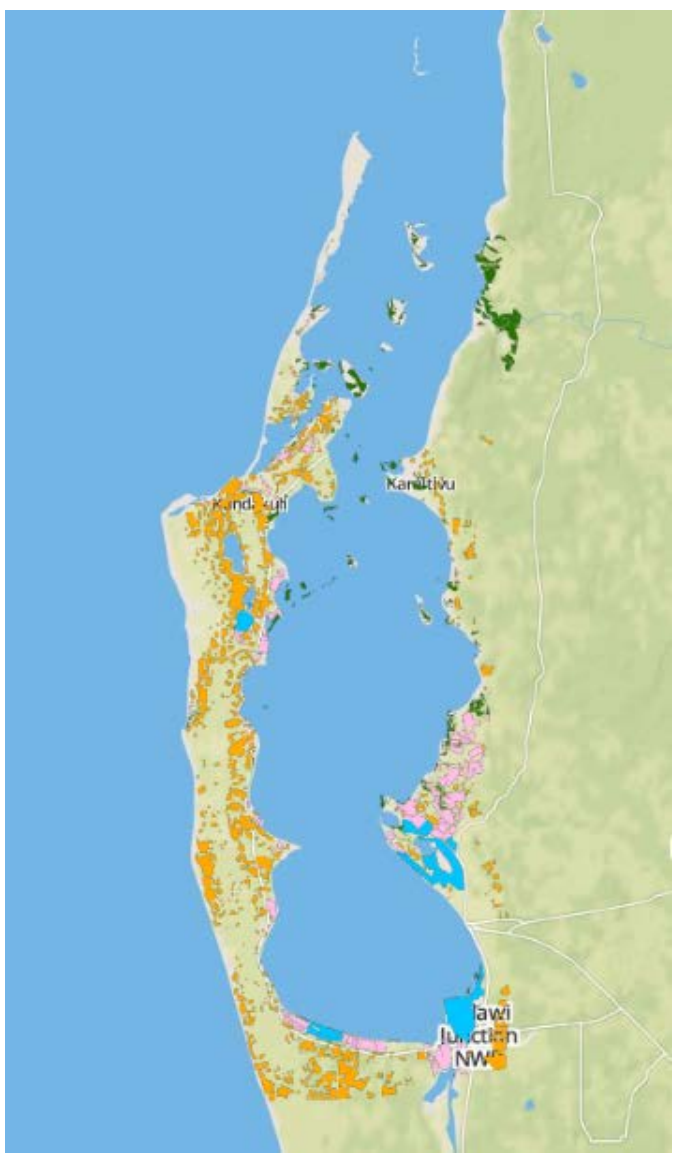

\subsection{Puttalam Lagoon}

The focus of the current paper is on the area around Puttalam Lagoon, a site that has been particularly impacted by the recent history of aquaculture in Sri Lanka (Bournazil et al. 2015). The lagoon area consists of three Secretariat Divisions (SD), i.e. Puttalam, Kalpitiya and Wanathawilluwa (IUCN 2008), (Figure 1). In 2012, the population in Puttalam District was 759,800 with a population density of 264 persons $/ \mathrm{km}^{2}$ (2012 Census). The majority of people were engaged in fishing and related activities (40\%) and agriculture (29\%); a smaller proportion (15\%) worked in salt production or government services (Ranasinghe 2010). The unemployment rate in the North Western Province, of which Puttalam is a district, was $4.8 \%$. The percentage of poor households in Puttalam based on the Household Income and Expenditure survey 2012/13 is $5.1 \%$ (Dep of Census and Statistics 2015).

Figure 1 Puttalam Lagoon with indicated shrimp ponds (pink), salt pans (blue), mangroves (green) and coconut plantations (orange). Image produced by Ecometrica for the iCOAST project.

\subsection{Policy framework}

\footnotetext{
${ }^{2}$ http://www.cs.nw.gov.lk/cs/index.php?option=com_content\&view=article\&id=98\&/temid=236\&lang=en
} 
The National development plan Mahinda Chintana sets out priorities for economic development (Department of National Planning 2013). The focus for 2014-2016 is on economic development, infrastructure, and education. The plan does not, however, mention sustainability and climate change as priority influences on planning. Therefore, these issues need to be addressed through other policy instruments. The Coast Conservation and Coastal Resources Management Department (CC\&CRMD), responsible for the implementation of the Coastal Zone Management Plan, acknowledges the need to include climate change in coastal planning and it supports ecosystem restoration. As part of the plan, Special Area Management (SAM) of aquaculture sites has been designated. The Central Environmental Authority (CEA), responsible for the implementation of the Sri Lanka National Strategy Action Plan (NSAP), advocates an integrated ecosystem approach (MFF 2014). The CEA, however, does not have any legal mandate in the North Western Province (NWP) as in this council area, the National Environmental Act has been replaced by the NWP environmental statute.

Today, the management rights over coastal resources are vested within several state entities with overlapping mandates (Kekulandala pers. comm.). Although the Puttalam Lagoon is managed under a single piece of legislation, the Coast Conservation Act (1981), there are numerous institutions playing a role in development plans; these include the CC\&CRMD, the Department of Fisheries and Aquatic Resources (DFAR), the Department of Wildlife Conservation (DWC), the Department of Forest Conservation (DFC), the Urban Development Authority (UDA) and the District Secretary Puttalam. Each of these are managing different sub-sectors of Puttalam Lagoon. This situation hampers the development planning processes, and a harmonization of all the plans and sectoral policies is vital to allow for CCD to take place.

\section{Puttalam shrimp farm characteristics}

Puttalam Lagoon with its mangroves, salt marshes and relatively easy accessibility is well suited for aquaculture (Munasinghe et al. 2010). Between 1981-1992, approximately 33\% of mangroves were converted to shrimp farms (Pathirana et al. 2008). Shrimp farming grew exponentially and between 1992 to2012, 42\% of the remaining mangrove cover was removed (Bournazel et al. 2015). In 1996, the expansion of the shrimp industry halted abruptly after the first outbreak of White Spot Syndrome Virus (WSSV). It caused a 70\% drop in exported shrimp products (Munasinghe et al. 2010). After a revival, the final outbreak in 2004 caused the industry to collapse (Drengstig et al. 2005). In 2010, the number of shrimp farms in Puttalam District registered by NAQDA was 1176, but Munasinghe et al. (2010) found that only 603 were actually operational. The current area dedicated to shrimp farming around the lagoon is 1140 ha (ibid.). However more recent analyses of signs of activity and abandonment in the farms, using satellite imagery, suggest that more than $90 \%$ of farms in the area are non-operational (Bournazil et al. 2015).

The existing resource governance system in the North Western Province is a multi-level institutional structure (Galappaththi 2013). Puttalam District is divided into 31 shrimp farming sub zones from which the farmers are organised into shrimp farmers associations. Activities of individual farms, however, are not coordinated and short-term individual interests still prevail (Munasinghe et al. 2010).

\subsection{Current situation}


The current number of functional shrimp farms in Puttalam Lagoon is estimated at 126 (Jayasinghe, pers. comm.). The large farms with $>20$ ponds that were common in the past have largely disappeared and the sector is characterised by what is called 'backyard farming' where local people own 1-4 ponds of 0.4 ha each. These small farms can produce $4000-6000 / \mathrm{kg} / \mathrm{ha} /$ year, but premature harvests of undersized shrimp are common if an outbreak of WSSV is expected. These small shrimps ( $<25 \mathrm{gr}$ ) were previously sold at the local market at low prices. The current production is therefore less than optimal, since sustainable production in the current market would significantly increase export income to Sri Lanka. The underlying cause of this lies largely in inadequate management practices and unsuitable technologies to obtain a sustainable production (Munasinghe et al. 2010).

Low dissolved oxygen levels or fluctuations in salinity and water temperatures in the ponds are primary factors which activate WSSV (Direkbusarakom and Danayodol 1998; Hargreaves 1998). It is therefore crucial that stocking densities are kept low and that appropriate water quality is maintained. To prevent cross-contamination by disease and pollution, it is important that water resources are kept separate (Kautsky et al. 2000; Vanpatten 2004; Hoa et al. 2011). None of these measures are currently common and this leads to major problems. Currently, over $98 \%$ of the wild brood stock in the Puttalam-Chilaw area is infected with the WSSV virus. The open pond systems discharge effluents into the lagoon or to the Dutch Canal causing downstream farmers to fill their ponds with contaminated water. The sludge that is removed from the ponds is polluted with chemicals and poses an environmental risk. The sourcing of ground water for aquaculture has negatively affected the water balance and salinity. The construction of dykes and other structures further affected the hydrology, making it more difficult to maintain the water quality in the ponds, especially after heavy rainfall or during dry periods. The energy used for aquaculture (diesel, electricity) is substantial ( $25 \%$ of production costs) and leads to high $\mathrm{CO}_{2}$ emissions. Another main cost is feed (20-40\% of the production costs) of which the shrimp absorb only $20-30 \%$ leaving a high level of residues in the pond water (Avnimelech 2006).

As a result of the above, the sector is characterised by land use conflicts, low employment, a decreased scale of production, low profit margins, fluctuating prices, and a weak market position (Dahdouh-Guebas et al. 2002; Avnimelech 2006; GESAMP 2008; Munasinghe et al. 2010). In short, Shrimp farming in Puttalam, initially promoted as a development opportunity by the government, has led to an environmental, social and economic disaster. The impacts of climate change are expected to worsen these effects. Yet, at this point in time, no specific actions are being taken to reduce the vulnerability to climate change.

\section{Options for rehabilitation of shrimp farms and mangroves}

\subsection{Restoration of deserted shrimp farms}

A 2012 assessment of the shrimp farms in Puttalam Lagoon shows that $90 \%$ of the ponds are not functioning (Bournazel et al. 2015). The changes in the hydrology and high levels of unproductive saline and acid sulphate soils make the deserted ponds unsuitable for agriculture (Jayasinghe 1995; Tho et al. 2008; Tanavud 2010). Only a marginal percentage has been converted into coconut plantations (Kumara pers. comm.). About 10ha has been converted to salt pans (Bournazel et al. 2015). The Midterm Policy Framework 2013-2016 for Fisheries suggests that the deserted shrimp ponds could be utilized for aquaculture of milkfish, Asian sea-bass and tilapia (NAQDA 2012). 
However, the release of lands to investors has resulted in delays and some of the land is now used for infrastructure and housing.

\subsection{Application of international standards}

The current demand for sustainably produced shrimp from Europe (LEI 2012) and interest from the private sector (Drengstig 2013a, 2014) provide new options for the rehabilitation of shrimp farms in Puttalam. However, in order to be able to export shrimp to Europe and other high-end markets, stringent quality and food safety standards have to be met (Munasinghe et al. 2012). A number of standards for sustainable shrimp aquaculture have been developed with the purpose of minimising the risk of disease, preserving wild stocks, increasing food safety and social responsibility, and enhancing traceability. The best known are the Best Aquaculture Practices (BAP) of the Global Aquaculture Alliance ${ }^{3}$, the Aquaculture Stewardship Council (ASC) developed by WWF ${ }^{4}$, and Global G.A.P. that was developed by retailers ${ }^{5}$. To meet these standards, large investments are required, but a stable, high production will make these investments worthwhile.

\subsection{Mangrove rehabilitation}

The concept of using ecosystems as a basis to adapt to the impacts of changes in climate has gained momentum in recent years (Travers et al. 2012). The restoration of wetland vegetation and mangroves therefore is crucial (Danielsen 2009). Previous mangrove restoration programmes have generally not been successful as they were not adapted to local stressors (M.P. Kumara pers. obs.). However, some places already show natural rehabilitation of mangroves which can be facilitated by removing bunds and restoring the natural hydrological regime. The planting of marsh plants (Salicornia sp) in abandoned ponds is another option that has an additional benefit as a food source. The natural regeneration of mangroves and other vegetation, in combination with well-designed replanting programmes, will not only support the ecosystem functions and hydrology, it also positively contribute to carbon absorbance and sequestration.

\section{A future for CCD shrimp aquaculture in Puttalam}

The Government of Sri Lanka continues to promote shrimp farming, including in pristine areas that were formerly inaccessible due to the civil war. However, in order to learn from previous mistakes and build a long-term economically viable industry, a new approach to shrimp farming is required. Various researchers have provided recommendations for sustainable development of the sector (Primavera 2006; Ranasinghe 2010).

In order to meet the demands from external markets, both new as well as restored shrimp farms will have to operate in a manner that is in line with international standards for sustainability and food security. The sector will need to apply sound management practices that could effectively deal with WSSV outbreaks and technical interventions need to be introduced that reduce GHG emissions and allow for adaptation to climate change effects. Re-establishment of natural ecosystems, including mangrove restoration, is an important aspect of this.

For Puttalam Lagoon, a scenario for Climate Compatible Development (CCD) could look as follows:

\footnotetext{
${ }^{3}$ http://www.gaalliance.org/bap/standards.php

${ }^{4}$ http://www.asc-aqua.org/

${ }^{5}$ http://www.globalgap.org/uk_en/for-producers/aquaculture/
} 


\subsection{Technical interventions}

The areas that show natural regeneration of mangroves and wetland vegetation would be protected while in other key areas, mangroves would be restored leading to the re-establishment of buffer zones, filtration areas, and a habitat for marine species, including shrimp. New farms would be built in line with the carrying capacity of the ecosystem and with provisions to counter the effects of climate change, including the construction of flood canals and dikes around the farm. There should be a total ban on further destruction of mangrove systems. The preference would be for closed aquaculture systems as they are less dependent on water availability, whilst effluent into the surrounding water bodies is minimal. To reduce the risk of disease, farms should be set up with ample space between ponds and between farms; the interstitial vegetation would serving as a buffer. Existing farms would implement technical measures to bring them up to standard, reduce spread of disease and increase production. Proper pond preparation, water treatment, the screening of the shrimp for disease and acclimatization are a few of these measures. The use of probiotics and application of chemicals and food would be closely monitored to optimise the pond water quality.

On the basis of the international standards and expert meetings, the following specific interventions were highlighted as they contribute to all three CCD variables, i.e. adaptation, mitigation and development (Table 1).

\begin{tabular}{|c|c|c|c|c|c|}
\hline & $\begin{array}{l}\text { Technical } \\
\text { interventions } \\
\text { for CCD shrimp } \\
\text { farming }\end{array}$ & Adaptation & Mitigation & Development & $\begin{array}{c}\text { Implementation } \\
\text { rate }\end{array}$ \\
\hline 1 & $\begin{array}{l}\text { Green buffer } \\
\text { zones, e.g. } \\
\text { mangroves. }\end{array}$ & $\begin{array}{l}\text { Reduce present } \\
\text { vulnerability to } \\
\text { floods, heat waves, } \\
\text { and heavy rainfall. } \\
\text { Supports resilience to } \\
\text { sea level rise } \\
\text { (including sediment } \\
\text { accretion and soil } \\
\text { elevation against sea- } \\
\text { level rise). }\end{array}$ & $\begin{array}{l}\text { Carbon } \\
\text { absorption and } \\
\text { sequestration. }\end{array}$ & $\begin{array}{l}\text { Extra income (i.e. } \\
\text { wood) and } \\
\text { availability NTFP. } \\
\text { Preserves } \\
\text { biodiversity and } \\
\text { ecosystem services } \\
\text { e.g. aesthetic value } \\
\text { for tourism. }\end{array}$ & $\begin{array}{l}\text { Occasionally in } \\
\text { new farms. } \\
\text { Lack of } \\
\text { institutional and } \\
\text { financial support } \\
\text { to establish } \\
\text { buffer zones. } \\
\text { Failed planting } \\
\text { activities in the } \\
\text { inter-tidal zones. }\end{array}$ \\
\hline 2 & $\begin{array}{l}\text { Increase land } \\
\text { margins } \\
\text { between ponds } \\
\text { and between } \\
\text { farms. }\end{array}$ & $\begin{array}{l}\text { Diminishes risk of soil } \\
\text { erosion, flooding, and } \\
\text { pond water } \\
\text { evaporation. }\end{array}$ & $\begin{array}{l}\text { Carbon } \\
\text { absorption and } \\
\text { sequestration. }\end{array}$ & $\begin{array}{l}\text { Prevents spreading } \\
\text { diseases and } \\
\text { closures of farms. }\end{array}$ & $\begin{array}{l}\text { Easiest in newly } \\
\text { developed areas. }\end{array}$ \\
\hline 3 & $\begin{array}{l}\text { Recirculating } \\
\text { Aquaculture } \\
\text { System (RAS). }\end{array}$ & $\begin{array}{l}\text { Reduces pressure on } \\
\text { environment and } \\
\text { hydrology. }\end{array}$ & $\begin{array}{l}\text { Water pump } \\
\text { may increase } \\
\mathrm{CO}_{2} \text { emissions } \\
\text { unless } \\
\text { renewables are } \\
\text { used. }\end{array}$ & $\begin{array}{l}\text { Increases } \\
\text { production. } \\
\text { Supports } \\
\text { sustainability. }\end{array}$ & $\begin{array}{l}\text { Few farms have } \\
\text { applied this. }\end{array}$ \\
\hline 4 & Closed systems. & $\begin{array}{l}\text { Reduces water use. } \\
\text { Reduced dependency } \\
\text { on water availability. }\end{array}$ & $\begin{array}{l}\text { Reduces } \mathrm{CO}_{2} \\
\text { emissions as less } \\
\text { energy required } \\
\text { to pump water } \\
\text { in/out. }\end{array}$ & Reduces pollution. & $\begin{array}{l}\text { Practiced by } \\
\text { small scale } \\
\text { farmers who do } \\
\text { not have space } \\
\text { to develop a } \\
\text { RAS. }\end{array}$ \\
\hline
\end{tabular}




\begin{tabular}{|c|c|c|c|c|c|}
\hline 5 & $\begin{array}{l}\text { Removal of } \\
\text { sediments from } \\
\text { pond bottom } \\
\text { and farm area. }\end{array}$ & $\begin{array}{l}\text { Reduces pollution. } \\
\text { Reduces dissolution } \\
\text { of toxins. }\end{array}$ & Releases carbon. & $\begin{array}{l}\text { Reduces disease. } \\
\text { Sediment can be } \\
\text { used as fertilizer in } \\
\text { other land uses. }\end{array}$ & $\begin{array}{l}\text { At the moment } \\
\text { the sediment is } \\
\text { removed from } \\
\text { the ponds, but } \\
\text { dumped next to } \\
\text { the pond. }\end{array}$ \\
\hline 6 & $\begin{array}{l}\text { Nets to filter } \\
\text { incoming water } \\
\text { from the } \\
\text { lagoon. }\end{array}$ & $\begin{array}{l}\text { Prevents algae and } \\
\text { particles from } \\
\text { entering the pond. }\end{array}$ & $\begin{array}{l}\text { No } \mathrm{CO}_{2} \\
\text { emissions. }\end{array}$ & $\begin{array}{l}\text { More efficient } \\
\text { pond management: } \\
\text { removal of algae } \\
\text { and particles is } \\
\text { costly. } \\
\text { Prevents spreading } \\
\text { of disease. }\end{array}$ & $50 \%$ \\
\hline 7 & $\begin{array}{l}\text { Improved } \\
\text { aeration. }\end{array}$ & $\begin{array}{l}\text { Reduces pollution } \\
\text { and accumulation of } \\
\text { toxic gases in the } \\
\text { pond water. }\end{array}$ & $\begin{array}{l}\text { Higher energy } \\
\text { use and thus } \\
\mathrm{CO}_{2} \text { emissions. }\end{array}$ & $\begin{array}{l}\text { Increases } \\
\text { production. }\end{array}$ & $75 \%$ \\
\hline 8 & $\begin{array}{l}\text { Usage of stock } \\
\text { tanks. }\end{array}$ & $\begin{array}{l}\text { Allows dealing with } \\
\text { water availability and } \\
\text { fluctuations in water } \\
\text { levels in pond. }\end{array}$ & $\begin{array}{l}\text { Higher energy } \\
\text { use and thus } \\
\mathrm{CO}_{2} \text { emissions. }\end{array}$ & $\begin{array}{l}\text { Increases and } \\
\text { stabilises } \\
\text { production. }\end{array}$ & $10 \%$ \\
\hline 9 & $\begin{array}{l}\text { Healthy } \\
\text { stocking density }\end{array}$ & $\begin{array}{l}\text { Fluctuating water } \\
\text { temperature due to } \\
\text { climate change will } \\
\text { not allow for high } \\
\text { stocking densities. }\end{array}$ & $\begin{array}{l}\text { Moderate } \\
\text { stocking } \\
\text { densities will } \\
\text { reduce energy } \\
\text { consumption. }\end{array}$ & $\begin{array}{l}\text { Reduces risk of } \\
\text { disease outbreaks. } \\
\text { Smaller, but more } \\
\text { stable production. }\end{array}$ & $60 \%$ \\
\hline 10 & $\begin{array}{l}\text { Use of natural } \\
\text { foods, e.g. } \\
\text { plankton is a } \\
\text { natural food for } \\
\text { PL. }\end{array}$ & $\begin{array}{l}\text { Provision of natural } \\
\text { food may enhance } \\
\text { natural immunity of PLs } \\
\text { against diseases caused } \\
\text { by effects of climate } \\
\text { change. }\end{array}$ & $\begin{array}{l}\text { Enhances the } \\
\text { natural } \\
\text { planktonic } \\
\text { productivity in } \\
\text { the water. This } \\
\text { growth } \\
\text { absorbs } \\
\text { atmospheric } \\
\text { carbon. }\end{array}$ & $\begin{array}{l}\text { Better quality } \\
\text { shrimp. Feeding } \\
\text { PLs on plankton } \\
\text { reduces the cost } \\
\text { of feed. }\end{array}$ & Few \\
\hline 11 & $\begin{array}{l}\text { Fresh water } \\
\text { collection tanks } \\
\text { (during wet } \\
\text { season). }\end{array}$ & $\begin{array}{l}\text { Reduces reliance on } \\
\text { wells and ground water. }\end{array}$ & $\begin{array}{l}\text { Reduces } \\
\text { energy that is } \\
\text { normally } \\
\text { needed to } \\
\text { purify water. }\end{array}$ & $\begin{array}{l}\text { Increases } \\
\text { availability of } \\
\text { fresh water. }\end{array}$ & $\begin{array}{l}\text { Few farms have } \\
\text { these, mainly for } \\
\text { drinking water. }\end{array}$ \\
\hline 12 & $\begin{array}{l}\text { Effluent } \\
\text { treatment } \\
\text { ponds. }\end{array}$ & $\begin{array}{l}\text { Reduces pollution of } \\
\text { particles and chemical } \\
\text { tracers in the } \\
\text { environment. } \\
\text { Reduces risk of algae } \\
\text { blooms caused by high } \\
\text { nutrient levels in } \\
\text { effluents. }\end{array}$ & $\begin{array}{l}\text { Conserves } \\
\text { biodiversity. } \\
\text { The aquatic } \\
\text { weeds in the } \\
\text { tanks absorb } \\
\text { nutrients as } \\
\text { well as carbon. }\end{array}$ & $\begin{array}{l}\text { Prevents } \\
\text { spreading of } \\
\text { diseases. } \\
\text { Preserves the } \\
\text { natural lagoon } \\
\text { environment on } \\
\text { the longer term. }\end{array}$ & Few \\
\hline 13 & $\begin{array}{l}\text { Combine } \\
\text { shrimp farming } \\
\text { with other } \\
\text { species, e.g. } \\
\text { mud crab or } \\
\text { milkfish. }\end{array}$ & $\begin{array}{l}\text { Increases ability to } \\
\text { adapt to changing } \\
\text { circumstances } \\
\text { (diversification). } \\
\text { Reduces pressure on } \\
\text { water sources. }\end{array}$ & $\begin{array}{l}\text { Plankton or } \\
\text { aquatic weed } \\
\text { produced to } \\
\text { feed herbivore } \\
\text { fish help } \\
\text { absorb }\end{array}$ & $\begin{array}{l}\text { Promotes food } \\
\text { security and a } \\
\text { stable income. } \\
\text { Reduces risk and } \\
\text { spread of disease. }\end{array}$ & $\begin{array}{l}\text { New } \\
\text { introduction. }\end{array}$ \\
\hline
\end{tabular}




\begin{tabular}{|c|c|c|c|c|c|}
\hline & & & $\begin{array}{l}\text { atmospheric } \\
\text { carbon. }\end{array}$ & & \\
\hline 14 & $\begin{array}{l}\text { Renewable } \\
\text { energy (wind, } \\
\text { solar) }\end{array}$ & $\begin{array}{l}\text { Reduces dependency } \\
\text { on fossil fuels. } \\
\text { Reduces environmental } \\
\text { damage (cutting wood). }\end{array}$ & $\begin{array}{l}\text { Reduces } \mathrm{CO}_{2} \\
\text { emissions. } \\
\text { Reduces } \\
\text { pollution from } \\
\text { oil spills. }\end{array}$ & $\begin{array}{l}\text { Provides secure } \\
\text { and clean energy } \\
\text { supply. } \\
\text { Reduces costs on } \\
\text { long term. } \\
\text { Supports } \\
\text { environmental } \\
\text { sustainability. }\end{array}$ & $\begin{array}{l}0 \% \text {. High initial } \\
\text { investments } \\
\text { required. }\end{array}$ \\
\hline
\end{tabular}

Table 1 Technical interventions that support CCD in aquaculture.

\subsection{Management interventions}

It is now acknowledged that low intensity but sustainable harvesting has far greater long-term value to local stakeholders and the wider community than large shrimp farm aquaculture developments (Gunawardena and Rowan 2005). The implementation of international guidelines, existing Best Management Practices and specific procedures around disease outbreak would prevent disease and pollution leading to higher, more stable production. Coordination between shrimp farmers could happen through the shrimp farmers' association or other local organisations, such as the samithi or sangamaya. Community empowerment, institutional strengthening, and capacity building for management could support these local organisations (Dayaratne et al. 1995; IUCN 2008).

If the farmers could manage to have full 120 day cycles and produce shrimp that are suitable for the export market (>25 gr), revenues would increase substantially. Due to the current large market demand, prices are high reaching $900-1200$ rupees/ $\mathrm{kg}$ for $+20 \mathrm{gr}$, hence there is a major opportunity to invest for the long-term. Adaption to diversification of culturing species and the use of biofilters would reduce the risk of disease and fluctuations in production, whilst generating a potential extra income. Duckweeds, algae, seaweeds and molluscs are known examples of species that enhance aquaculture production (Cattermoul and Devendra 2002). Adding value at the local level, e.g. processing and packaging of shrimp, could further improve people's income (Jayantha and De Silva 2010). This would allow farmers to accumulate funds to invest in renewable energy. This would not only reduce energy costs and avoid power cuts, but substantially reduce $\mathrm{CO}_{2}$ emissions.

On farm research and monitoring will allow the industry to learn, adapt and improve. Education will enable farmers to better understand the production system and implications of improper management, creating an incentive to shift to a more sustainable approach. Improvement of workers' social conditions and application of health and safety standards, will lead to an overall healthier sector, whilst servicing foreign market demands.

Other management interventions that are specifically beneficial in supporting the three components of CCD are listed in Table 2.

\begin{tabular}{c|c|c|c|c|}
$\begin{array}{c}\text { Management } \\
\text { interventions in } \\
\text { shrimp farming }\end{array}$ & Adaptation & Mitigation & Development & $\begin{array}{c}\text { Implementation } \\
\text { rate }\end{array}$ \\
\hline
\end{tabular}




\begin{tabular}{|c|c|c|c|c|c|}
\hline 1 & $\begin{array}{l}\text { Cluster farming } \\
\text { (smaller farms } \\
\text { organised under sub } \\
\text { zonal farmer } \\
\text { societies. }\end{array}$ & $\begin{array}{l}\text { Greater ability to } \\
\text { deal with } \\
\text { environmental } \\
\text { change. }\end{array}$ & $\begin{array}{l}\text { Communal } \\
\text { procurement } \\
\text { of renewable } \\
\text { energy sources }\end{array}$ & $\begin{array}{l}\text { Improved farm } \\
\text { management and } \\
\text { regulation of inlet } \\
\text { and effluent } \\
\text { water, and } \\
\text { improved } \\
\text { knowledge lead to } \\
\text { higher profits and } \\
\text { more stability. }\end{array}$ & $\begin{array}{l}\text { Although there } \\
\text { are shrimp } \\
\text { farmers } \\
\text { associations, the } \\
\text { activities of } \\
\text { individual farms, } \\
\text { are not } \\
\text { coordinated. }\end{array}$ \\
\hline 2 & $\begin{array}{l}\text { Presence of } \\
\text { functional } \\
\text { management bodies. }\end{array}$ & $\begin{array}{l}\text { Greater ability to } \\
\text { deal with } \\
\text { environmental } \\
\text { change and taking } \\
\text { measures. }\end{array}$ & $\begin{array}{l}\text { Possibility to } \\
\text { collectively } \\
\text { generate } \\
\text { renewable } \\
\text { energy. }\end{array}$ & $\begin{array}{l}\text { Better bargaining } \\
\text { power producers } \\
\text { and higher } \\
\text { production lead } \\
\text { to higher profits. } \\
\text { Stimulates } \\
\text { exchange of } \\
\text { information and } \\
\text { knowledge. }\end{array}$ & $\begin{array}{l}\text { Almost all } \\
\text { farmers are } \\
\text { organized in } \\
\text { shrimp farm } \\
\text { associations. }\end{array}$ \\
\hline 3 & $\begin{array}{l}\text { Proper designation of } \\
\text { (new) shrimp farm } \\
\text { areas. }\end{array}$ & $\begin{array}{l}\text { Planning ponds } \\
\text { beyond the } \\
\text { intertidal zone and } \\
\text { in the mangrove } \\
\text { areas protect the } \\
\text { mangroves and } \\
\text { reduces the } \\
\text { potential effects of } \\
\text { sea level rising. } \\
\text { Prohibition of } \\
\text { ponds in salt } \\
\text { marshes protects } \\
\text { sensitive } \\
\text { ecosystems. }\end{array}$ & $\begin{array}{l}\text { Protects } \\
\text { coastal carbon } \\
\text { sinks. }\end{array}$ & $\begin{array}{l}\text { Supports } \\
\text { development of } \\
\text { shrimp industry } \\
\text { with less damage } \\
\text { to mangroves and } \\
\text { salt marshes. }\end{array}$ & Unclear \\
\hline 4 & $\begin{array}{l}\text { Application of Best } \\
\text { Management } \\
\text { Practices (BMPs). }{ }^{6}\end{array}$ & $\begin{array}{l}\text { Greater ability to } \\
\text { deal with } \\
\text { environmental } \\
\text { change and taking } \\
\text { measures. }\end{array}$ & $\begin{array}{l}\text { Reduces } \\
\text { energy use. }\end{array}$ & $\begin{array}{l}\text { Improves farm } \\
\text { performance. }\end{array}$ & $\begin{array}{l}\text { Partly (depending } \\
\text { on costs). }\end{array}$ \\
\hline 5 & Zonal crop calendar. & $\begin{array}{l}\text { Increases } \\
\text { flexibility in use of } \\
\text { ponds. }\end{array}$ & $\begin{array}{l}\text { Reduces } \\
\text { energy use. }\end{array}$ & $\begin{array}{l}\text { Reduces disease } \\
\text { outbreaks and } \\
\text { improves } \\
\text { production. }\end{array}$ & $100 \%$ \\
\hline 6 & $\begin{array}{l}\text { Improved compliance } \\
\text { with regulations. }\end{array}$ & $\begin{array}{l}\text { Increases } \\
\text { effectivity of } \\
\text { production, i.e. } \\
\text { flexible to } \\
\text { changing } \\
\text { circumstances. }\end{array}$ & $\begin{array}{l}\text { Reduces } \\
\text { emissions. }\end{array}$ & $\begin{array}{l}\text { Increases equity } \\
\text { (shared benefits) } \\
\text { and productivity. }\end{array}$ & Partly \\
\hline 7 & $\begin{array}{l}\text { Good pond } \\
\text { management. }\end{array}$ & $\begin{array}{l}\text { Increases ability to } \\
\text { deal with changes } \\
\text { in water quality } \\
\text { and temperature. }\end{array}$ & $\begin{array}{l}\text { Reduces } \\
\text { emissions } \\
\text { through } \\
\text { increased } \\
\text { efficiency. }\end{array}$ & $\begin{array}{l}\text { Reduces disease } \\
\text { through lower use } \\
\text { of chemicals. } \\
\text { Increases } \\
\text { production. }\end{array}$ & $\begin{array}{l}\text { Good pond } \\
\text { management } \\
\text { includes the } \\
\text { interventions } \\
\text { below. }\end{array}$ \\
\hline 8 & $\begin{array}{l}\text { Regular feed } \\
\text { monitoring. }\end{array}$ & $\begin{array}{l}\text { Reduces pollution } \\
\text { of pond water and }\end{array}$ & $\begin{array}{l}\text { Reduces } \\
\text { emissions. }\end{array}$ & $\begin{array}{l}\text { Improves Food } \\
\text { Conversion Ratio }\end{array}$ & $100 \%$ \\
\hline
\end{tabular}

\footnotetext{
${ }^{6}$ Most of the suggested interventions fall under the Best Management Practices.
} 


\begin{tabular}{|c|c|c|c|c|c|}
\hline & & effluent. & & (FCR). & \\
\hline 9 & $\begin{array}{l}\text { Issuing of } \\
\text { Environmental } \\
\text { protection licenses. }\end{array}$ & $\begin{array}{l}\text { Reduces } \\
\text { environmental } \\
\text { risks, safeguards } \\
\text { fish breeding areas } \\
\text { and buffer zones. }\end{array}$ & $\begin{array}{l}\text { Increases } \\
\text { carbon sinks. }\end{array}$ & $\begin{array}{l}\text { Supports income, } \\
\text { health and well- } \\
\text { being on longer } \\
\text { term. }\end{array}$ & $\begin{array}{l}\text { Only larger } \\
\text { farms. Regular } \\
\text { monitoring is still } \\
\text { an issue. }\end{array}$ \\
\hline 10 & $\begin{array}{l}\text { Value addition to } \\
\text { products. }\end{array}$ & $\begin{array}{l}\text { Reduces pressure } \\
\text { on resources due } \\
\text { to higher income. }\end{array}$ & $\begin{array}{l}\text { Supports } \\
\text { potential to } \\
\text { invest in } \\
\text { renewable } \\
\text { energy. }\end{array}$ & $\begin{array}{l}\text { Improves income } \\
\text { at the local level. }\end{array}$ & $\begin{array}{l}\text { Adding value } \\
\text { happens now } \\
\text { only at level of } \\
\text { processors. }\end{array}$ \\
\hline 11 & $\begin{array}{l}\text { Application of } \\
\text { Environmental } \\
\text { Impact Assessments } \\
\text { (EIA). }\end{array}$ & $\begin{array}{l}\text { Supports shrimp } \\
\text { farming that is } \\
\text { more compatible } \\
\text { with } \\
\text { hydrology/carrying } \\
\text { capacity of } \\
\text { ecosystem. }\end{array}$ & $\begin{array}{l}\text { Supports } \\
\text { protection of } \\
\text { coastal carbon } \\
\text { sinks such as } \\
\text { mangroves }\end{array}$ & $\begin{array}{l}\text { More sustainable } \\
\text { shrimp industry } \\
\text { on the long term. }\end{array}$ & $\begin{array}{l}\text { Developments } \\
\text { over } 4 \text { ha need } \\
\text { EIA. However, } \\
\text { criteria need to } \\
\text { be adapted to } \\
\text { new insights. }\end{array}$ \\
\hline
\end{tabular}

Table 2 Management interventions that support CCD in aquaculture.

In order to make the shift to shrimp farming in line with Climate Compatible Development, technical interventions need to be implemented at a broad scale. Together with better management practices, the sector will be more resilient in dealing with disease and climate change effects. The Lagoon Management Authority (LMA) and implementation of the Puttalam Lagoon Conservation Management Plan (PLCMP) as proposed by the IUCN can support the process (Ranasinghe 2010).

\section{Financial and regulatory mechanisms supporting CCD aquaculture}

The main barrier to make the shift to more sustainable aquaculture is an unfavourable investment climate. Small-holders often lack the financial means to implement new interventions (Munasinghe et al. 2010). Access to loans and insurance is difficult as interest rates are high and government support is lacking. In addition, the current legislative framework lacks coherence and is poorly implemented (Primavera 2006). Strong government leadership is required in combating these constraints (Ellis et al. 2013). After the recent president election, the Government of Sri Lanka has taken several measures to improve the investment climate, and is now dealing with reducing corruption and promoting aquaculture businesses in order to realise the potential in the sector. The following mechanisms have been identified to support a shift from the current situation to shrimp aquaculture that is in line with CCD:

\subsection{Policy mechanisms}

\section{Climate change mainstreaming}

Mainstreaming Climate Change Adaptation into Development Planning is vital (UNDP-UNEP 2011). The Climate Change Secretariat (CCS) already plays a vital role in developing the institutional and regulatory mechanisms to address climate change. The National Climate Change Adaptation Strategy could provide a framework in which to develop this synergy further. 
Aquaculture is regulated through the National Aquaculture Development Authority Act (No. 53 of 1998) with NAQDA as the implementing agency. The absence of a specific law for aquaculture causes the industry to be regulated under a variety of acts that are incoherent. Currently, there is an initiative to develop a master plan that would describe the development strategies, planning process, law enforcement and regulations. The initiative will also provide the stakeholders with the appropriate technologies and practical knowledge to set-up commercial aquaculture installations (Drengstig and Reithaug, in prep.). The process is supported by the FAO.

\section{Climate funds}

The World Bank and Global Environment Facility have several funds that focus on adaptation and mitigation, for example through REDD +. Also the EU and national governments are willing to provide funds to support countries adapt to climate change and embark on low carbon growth whilst supporting economic development.

\section{Education}

Training and education are key factors in understanding climate change and its effects on natural resources. Increased knowledge is necessary to provide effective guidance to the government, the different economic sectors and all other stakeholders.

\subsection{Strategic Mechanisms}

\section{Decentralisation and co-management}

The top down management approach adopted in Sri Lanka has had limited success in effectively managing local resources (Pathirana et al. 2008). For successful implementation of management measures at the district and local level, decision-making power needs to be transferred to lower government and local level organisations (Harkes 2006). Currently, co-management systems are being established (Galappaththi and Berkes 2015). These have had encouraging initial success in promoting effective co-ordination between groups of farms, in particular the use of a zonal crop calendar that acts to separate periods of production between areas to counter the spread of disease.

\section{Land tenure}

Current investments in the coastal zone have weakened traditional institutions and created uncertainty about land rights and access to coastal resources. Clear land tenure systems and collective management will support the sustainable use and protection of coastal resources and ecosystems.

\section{Sustainable financing and benefit sharing}

Sustainable financing and benefit sharing provide incentives for management of system services (Ranasinghe 2010). The UN Reducing Emissions from Deforestation and Forest Degradation (REDD+) 
programme and Payments for Ecosystem Services (PES) schemes allow for communities to engage in mangrove rehabilitation and conservation. Feasibility and potential for carbon storage and trading are discussed in Bournazel et al. (2015).

\subsection{Market mechanisms}

Trade with EU

Economic cooperation between the EU and Sri Lanka started in the late 1980s and has become an integral part of the EU's development strategy (EEAS 2014). The wide range of preferential trade agreements that the EU offers partners in the developing world allows them to benefit from relatively open access to the EU market, e.g. a largely tariff and quota free access (European Commission 2014). The current Government has initiated a dialogue with the EU just recently in order to gain market access to products from the fishery and aquaculture sector.

\section{Private sector involvement}

The interest rate has recently been drastically reduced, but a lack of match funding remains a disincentives for private companies to invest in Puttalam. Outside initiatives, such as NORAD's Business Matchmaking Programme, try to stimulate private sector involvement; this initiative has been successful in introducing more than 10 Norwegian technology suppliers from Norway to Sri Lanka. Recent political and cultural changes have generated a generally benign climate for investment, with both public and private stakeholders expressing optimism. Government support and the availability of insurance for business ventures should give banks the confidence to further support these investments.

\section{Mixed production systems}

Options to make shrimp farming more sustainable can involve mixed production systems (Primavera $2006)$ or a shift from black tiger shrimp ( $P$. monodon) to white shrimp ( $P$. vannamei). The latter is easier to produce and has a higher resistance to disease. However $P$. monodon attracts higher prices and there is in-country expertise in its production, so moving away from this species is not the preferred first option.

Aquaculture could also take place in combination with mangrove restoration. This would help reinstate the natural functions of mangroves, whilst providing local communities with firewood, poles, medicines and other non-timber forest products. Access and use could be part of a comanagement arrangement.

\subsection{Financial mechanisms}

\section{Licensing}

Licence conditions set out specific operational and reporting requirements for farms in order to operate legally. The provisions ensure that aquaculture sites are operated in an environmentally sustainable manner that minimizes the risk to wild fish stocks and marine resources. Stringent application of the licensing system is vital for successful development of commercial and industrial scale aquaculture. 
Taxes

Tax relief can be an important incentive to stimulate business investments. Examples are tax discounts, 'tax holidays', exemptions from duty on imports and turnover taxes (FAO 2001). Application of these benefits would provide an important incentive to revive the sector. The Board of Investment (BOI) have specific terms for foreign investment in Sri Lanka.

\section{Subsidies}

In 1991, the government withdrew subsidies to aquaculture because animal farming was felt to not be in accordance with the Buddhist culture of Sri Lanka (De Silva 1991). Now, with a renewed government interest in developing the sector (NAQDA 2012), subsidies could support revitalisation of sustainable shrimp culture in Puttalam.

\section{Conclusion and recommendations}

The benefits of functional mangroves and shrimp farms to the local population are widely acknowledged (Gunawardena and Rowan 2005; Bosire et al. 2008; Satyanarayana et al. 2013), but the current situation reflects a history of poor management and disregard for the welfare of the local poor and for long-term environmental sustainability. Given the Government's stated intention of increasing revenues from aquaculture what is the best way forward? With a total production of $3000-4000 \mathrm{mt}$ of shrimp/year, Sri Lanka is a relatively small global player. At the moment, the majority of shrimp farms are small-scale using simple technologies. Shrimp are harvested prematurely $(<20 \mathrm{gr})$ to avoid disease and thus can only be sold to the local market. Export of the larger shrimp (>25gr) is mostly to Japan, but accessing the European market would provide a great opportunity for shrimp farmers as the prices paid are higher. This is a viable option as demand for sustainable seafood in countries like Norway and the Netherlands is substantial (LEl report 2012, Drengstig 2013b). However, in order to access these markets, there are stringent requirements in terms of quality and food safety. Eco-labelling requires the application of standards such as those of the Aquaculture Stewardship Council (ASC) or Global G.A.P. An effective administration system needs to be set up to ensure traceability and quality control (van Duijn, pers. comm.). Investments in social security, education and health care for workers are needed to obtain an international sustainability certificate. To achieve this, there is a need for an entirely new model for aquaculture in Sri Lanka (Bournazel et al. 2015).

Whilst the standards of the ASC far exceed those that have historically prevailed in Sri Lanka, there are critics who see them as inadequate in. A global group of NGOs opposed to the ASC standards, called the Critical Outsiders Alliance, raise a wide range of concerns ${ }^{7}$. Key issues are fears that the ASC standards will still allow limited mangrove destruction, and that they do not sufficiently address the interests of local people. A truly sustainable future for aquaculture in Sri Lanka that genuinely complies with CCD, may thus involve going beyond the ASC guidelines and would certainly involve no further mangrove removal and whole-sale restoration of damaged sites. Hence although the technical and policy options outlined here would be important steps towards a healthier industry they would not ensure CCD. The concept is more radical, and more demanding, than can be accommodated by existing standards. An important broader debate (one that is beyond the scope of

\footnotetext{
${ }^{7}$ See http://korta.nu/asc-review
} 
the current paper) raised by the Critical Outsiders Alliance questions the wisdom of export-driven aquaculture - even aquaculture that is environmentally sound - in situations where local food security is not assured.

The rehabilitation process which is currently taking place should be taken as an opportunity to overcome past industry failures (Tejedor 2013). Furthermore, it is a chance to progressively transform aquaculture into a more sustainable, competitive sector that is resilient to climate change and able to effectively combat diseases. Shrimp farming in Puttalam needs to be tailored to the hydrology, carrying capacity and socio-cultural context of the Lagoon (Primavera 2006). In order to revive shrimp farming in Puttalam in a manner that is sustainable and supports the principles of CCD (adaptation, mitigation and development), it is required that the major players, i.e. the government, the private sector, the banks and the insurance companies work in unison to provide the conditions to allow for this development to take place.

Key to the development of a healthy, productive sector is the application of a 'package' of technical and management interventions, and the establishment of appropriate management structures. Access to the European market would provide a great incentive to invest in these improved production methods. A mechanism that allows for local stakeholder involvement is co-management as described by Galappaththi and Berkes (2015). This requires the devolution of management authority to the local level and support from NAQDA. Capacity building, training and education at the local level would allow for Puttalam farmers to improve their production process. NAQDA could initiate a programme for farms to support them in the certification process. As a result financial institutions may be more inclined to provide assistance to these farms.

The government has a pivotal role in creating a supportive business environment. A sound policy framework, including firm and visible support for the National Climate Change Adaptation Strategy, and stable, long-term development plans would provide stability. The availability of tax relief and subsidies would also stimulate investors to set up a business. If the government supports these businesses further by providing match funding, banks will be more inclined to issue loans with reasonable interest rates. This would allow for the development of sound business plans conforming to international standards, which could give access to lucrative Western markets. Demonstration Farms would be a strong tool to both convince the farmers and the government that sustainable aquaculture can be a viable business, which will subsequently stimulate insurance companies to issue insurances (Drengstig 2013b). These measures together would lead to a healthy investment climate. Shrimp farming could be transformed into a sector that is stable and productive, with a minimal impact on the environment, and a maximum ability to adapt to climate change effects.

\section{Acknowledgements}

The iCoast project is funded by the Climate \& Development Knowledge Network (CDKN) and carried out by Edinburgh Napier University (lead), LTS International, Birmingham University, KMFRI, Ruhuna University in Sri Lanka, in collaboration with Ecometrica and the Environment Management Group.

We are grateful for Estbaliz Diaz Tejedor and Jil Bournazel, the two research students connected to this project. Aside from the authors, other iCoast project team members have contributed to this study: Lesley King, Karin Viergever, Jayatissa Loku Pullukkuttige, Fiona Nunan. Finally, we want to thank aquaculture experts that have shared their knowledge: Santhana, Willem van der Pijl, 
AriePieter van Duijn, andPeter van der Heijden. And a special thanks to Bhathiya Kekulandala for his input.

This document is an output from a project funded by the UK Department for International Development (DFID) and the Netherlands Directorate-General for International Cooperation (DGIS) for the benefit of developing countries. However, the views expressed and information contained in it are not necessarily those of or endorsed by DFID, DGIS or the entities managing the delivery of the Climate and Development Knowledge Network, which can accept no responsibility or liability for such views, completeness or accuracy of the information or for any reliance placed on them.

\section{References}

Alongi, D.M (2008) Mangrove Forests: Resilience, Protection from Tsunamis, and Responses to Global Climate Change. Estuarine, Coastal and Shelf Science, Vol. 76: 1-13.

Avnimelech, Y. (2006) Bio-filters: The Need for a New Comprehensive Approach. Aquacultural Engineering, Vol. 34: 172-178.

Bournazel J., Kumara M.P., Viergever K., Morel V., Jayatissa L.P. and Huxham M. (2015) The Impacts of Shrimp Farming on Land-Use and Carbon Storage around Puttalam Lagoon, Sri Lanka. Ocean \& Coastal Management, Vol. 113: 18 - 28

Cattermoul, N. and Devendra, A. (2002) The Impacts of Shrimp Farming on Communities in the Chilaw Lagoon Area. Effective Management for Biodiversity Conservation in Sri Lankan Coastal Wetlands. Final Report A-V.

Census of Population and Housing (2012). Provisional Results Based on 5\% Sample. Department of Census and Statistics \& Ministry of Finance and planning http://www.statistics.gov.Ik/PopHouSat/CPH2011/Pages/Activities/Reports/CPH_2012_5Per _Rpt.pdf

Dahdouh-Guebas, F., T. Zetterstrom, P. Ronnback, M. Troell, A. Wickramasinghe and N. Koedam (2002) Recent Changes in Land-use in the Pambala-Chilaw Lagoon Complex (Sri Lanka) Investigated Using Remote Sensing and GIS: Conservation of Mangroves Vs. Development of Shrimp Farming. Environmental Development and Sustainability, Vol. 4: 185-200.

Dahdouh-Guebas, F., L.P. Jayatissa, D. Di Nitto, J.O. Bosire, D. Lo Seen and N. Koedam, (2005) How Effective Were Mangroves as a Defence Against the Recent Tsunami? Current Biology, Vol. 15(12): 443-447.

Danielsen, F., M.K.Sorensen, M.F. Olwig, V. Selvam, F. Parish, N.D. Burgess, T. Hiraishi, V.M. Karunagaran, M.S. Rasmussen, L.B. Hansen, A. Quarto, and N. Suryadiputra (2005) The Asian Tsunami: A Protective Role for Coastal Vegetation. Science Vol. 320 (5748): 643.

Dayaratne, P., A.B.A.K. Gunaratne and M.M. Alwis (1995) Research and Capacity Building for Sustainable Coastal Management. Ambio, Vol. 24(7/8): 402-410.

De Silva, J.A. and J.M.P.K. Jayasinghe (1993) The Technology and Economics of Small-scale Commercial Shrimp Farms in the West Coast of Sri Lanka. Journal of Aquaculture in the Tropics, Vol. 8(2): 141-149.

Department of Census and Statistics (2015) Poverty Indicators. Household Income and Expenditure Survey - 2012/13. Ministry of Policy Planning Economic Affairs, Child Youth and Cultural Affairs, Sri Lanka 
Department of National Planning (2010) Mahinda Chintana-Vision for the Future. The Development Policy Framework Government of Sri Lanka. Department of National Planning \& Ministry of Finance and Planning.

Department of National Planning (2013) Mahinda Chintana-Vision for the Future. Public Investment Strategy 2014-2016. Department of National Planning \& Ministry of Finance and Planning.

Direkbusarakom, P. and Y. Danayodol (1998) Effect of Oxygen Depletion on Some Parameters of the Immune System in Black Tiger Shrimp (Penaeus monodon). In Flegel T.W. (Ed.) Advances in shrimp biotechnology. National Center for Genetic Engineering and Biotechnology, Bangkok.

Donato, D.C. J. Boone Kauffman, D. Murdiyarso, S. Kurnianto, M. Stidham and M. Kanninen (2011) Mangroves among the most Carbon-rich Forests in the Tropics. Nature Geoscience, Vol. 4: 293-297

Drengstig, A. (2001). Report from preliminary investigation on the project: Sustainable shrimp farming, skill enhancement and production of new technology for the shrimp farming industry in Sri Lanka. HOBAS/NORAD report, Stavanger, Norway.

Drengstig, A., A. Bergheim \& J.M.P.K. Jayasinghe (2005). Effects on water quality and shrimp performance of new aeration technology in Sri Lankan pond culture. Report RF - Rogaland Research.

Drengstig, A. A. Bergheim \& B. Braaten (2004). Training Programme for the Shrimp Farming Industry in Sri Lanka. NIVA report SFO

Drengstig, A. (2013a) Aquaculture in Sri Lanka. History, Current Status, and Future Potential. Paper prepared for the AquaNor Exhibition 2013, Trondheim, Norway.

Drengstig, A. (2013b) Requirements for Establishing Commercial Aquaculture in Sri Lanka. Suggested Developing Strategies, National Implementation Policies and Road Map. Aqvisor, Norway.

Drengstig, A. (2014) Identifying Potential Pitfalls for Commercial Aquaculture in Sri Lanka. Report from the $2^{\text {nd }}$ Workshop held in Colombo, Sri Lanka, on 19 February 2014. 20 March 2014.

Drengstig, A. and B. Aspøy (2014) Report from Preliminary Visit to Sri Lanka 2014. Investigating the Potential for Smartfarm's Mussel Farming Technology in Commercial Scale. 10 March 2014.

Drengstig, A. \& I. Reithaug (in prep.). Development and operationalization of a Master Plan for aquaculture in Sri Lanka.

Ellis, K., A. Cambray and A. Lemma (2013) Drivers and Challenges for Climate Compatible Development. Climate and Development Knowledge Network, London.

Eng, C.T., J.N. Paw, and F.Y. Guarin (1989) The Environmental Impact of Aquaculture and the Effects of Pollution on Coastal Aquaculture Development in Southeast Asia. Marine Pollution Bulletin, Vol. 20(7): 335-343.

Erwin, K. L. (2009) Wetlands and global climate change: the role of wetland restoration in a changing world. Wetlands Ecology and Management, Vol. 17(1): 71-84.

EEAS (2014) Sri Lanka and the EU. European External Action Service. Available online at: http://eeas.europa.eu/delegations/sri_lanka/eu_sri_lanka/trade_relation/index_en.htm

European Commission (2014) Trade Export Helpdesk. Available at: http://exporthelp.europa.eu/thdapp/index.htm

Galappaththi, E.K. (2013) Community-based Shrimp Aquaculture in Northwestern Sri Lanka. Thesis Submitted to the Faculty of Graduate Studies of The University of Manitoba in Partial Fulfilment of the Requirements for the Degree of Master of Natural Resources Management (M.N.R.M.) Natural Resources Institute Clayton H. Riddell Faculty of Environment, Earth, and Resources University of Manitoba, Winnipeg, Manitoba. 
Galappaththi, E.K. and F. Berkes (2015) Can Co-management Emerge Spontaneously? Collaborative Management in Sri Lankan Shrimp Aquaculture. Marine Policy 60 (2015): 1-8

GESAMP (2008) Assessment and Communication of Environmental Risks in Coastal Aquaculture. Rome, FAO. IMO/FAO/UNESCO-IOC/UNIDO/WMO/IAEA/UN/UNEP Joint Group of Experts on Scientific Aspects of Marine Environmental Protection. Reports and Studies GESAMP No. 76: $198 \mathrm{pp}$.

Gunawardena, M. and J.S. Rowan (2005) Economic Valuation of a Mangrove Ecosystem Threatened by Shrimp Aquaculture in Sri Lanka. Environmental Management, Vol. 36(4): 535-550.

Hargreaves, J.A. (1998) Nitrogen Biogeochemistry of Aquaculture Ponds. Aquaculture, Vol. 166: 181212.

Harkes, I.H.T. (2006) Fisheries Co-Management, the Role of Local Institutions and Decentralisation in Southeast Asia. PhD Thesis, Leiden University, Netherlands.

Hoa, T.T.T., M.P Zwart, N.T. Phuong, J.M. Vlak and M.C.M. de Jong, (2011) Transmission of White Spot Syndrome Virus in Improved-extensive and Semi-intensive Shrimp Production Systems: A Molecular Epidemiology Study. Aquaculture Vol. 313(1-4): 7-14.

IUCN (2008) Ecological and Socio-Economic Assessments of Selected Sites of the Puttalam Lagoon Area. An Exercise to Select Pilot Sites for the BMZ Coastal Ecosystem Restoration Project.

IUCN (2009). Prawn farms: the Supreme Court and IUCN: on the ground impediments to conservation. BMZ Project Case Studies.

Jayantha, S.P.M. and D.A.M. de Silva (2010) Supply Chain Management in the Aquaculture Industry: The Case of Food Fish Aquaculture in Sri Lanka, Sabaragamuwa University Journal 2010, Vol. 9(1): 147-169.

Jayasinghe, J.M.P. and D.J. MacIntosh (1993) Disease Outbreaks in the Shrimp Culture Grow-out System of Sri Lanka. Tropical Agricultural Research, Vol. 5: 336-349.

Jayasinghe, J.M.P., S.L. Corea, P.K.M. Wijegunawardana (1994) Deterioration of Sanitary Conditions in Coastal Waters. Paper presented at the 20th WEDC Conference Colombo: Affordable Water Supply and Sanitation, Sri Lanka.

Jayasinghe, J.M.P.K. (1995) Sri Lanka: Report on Regional study and Workshop on the Environmental Assessment and Management of Aquaculture Development. Annex II-15, Sri Lanka. FAO, NACA.

Kautsky, N., H. Berg, C. Folke, J. Larsson and M. Troell (1997) Ecological Footprint as a Means for the Assessment of Resource Use and Development Limitations in Shrimp and Tilapia Aquaculture. Aquaculture Research, Vol. 28: 753-766.

Lei (2012) Sri Lanka Seafood Exports - Quick Scan of the EU Market Potential. Compiled for the Centre for the Promotion of Imports from Development Countries (CBI) by Wageningen University.

MFF (2014) Climate Change Impacts and Adaptation. http://www.mangrovesforthefuture.org/countries/members/sri-lanka/

Ministry of Environment of Sri Lanka (2011) Climate Change Vulnerability Data Book. Available via: www.climatechange.Ik.

Mitchell, T. and S. Maxwell (2010) Defining Climate Compatible Development. Policy Brief November 2010/A. Climate and Development Knowledge Network, London.

Mumby, P.J., A.J. Edwards, J.E. Arias-Gonzalez, K.C. Lindeman, P.G. Blackwell, A. Gall, M.I. Gorczynska, A.R. Harborne, C.L. Pescod, H. Renken, C.C.C. Wabnitz and G. Llewelly (2004) 
Mangroves Enhance the Biomass of Coral Reef Fish Communities in the Caribbean. Nature, Vol. 427: 533-536.

Munasinghe, M.N., C. Stephen, P. Abeynayake and I.S. Abeygunawardena (2010) Shrimp Farming Practices in the Puttalam District of Sri Lanka: Implications for Disease Control, Industry Sustainability, and Rural Development. Veterinary Medicine International, Volume 2010.

Munasinghe, M. N., C. Stephen, C. Robertson and P. Abeynayake (2012) Farm Level and Geographic Predictors of Antibiotic Use in Sri Lankan Shrimp Farms. Journal of Aquatic Animal Health, Vol. 24 (1):22-29.

Nap, G., L. King and M. Wilson (submitted) Participatory Visioning as a Tool for Climate Compatible Development Planning: a case study from Kenya. Submitted to Ambio.

NAQDA (2012) Fisheries statistics. Available at: http://www.naqda.gov.lk/index.php\# [Accessed $20^{\text {th }}$ January]. National Aquaculture Development Authority of Sri Lanka

Pathirana, K.P.P., A.R.I. Kamal, M.C. Riyas and A.L.M Safeek (2008) Management of Coastal Resources in Puttalam Lagoon, Sri Lanka. Paper No: P-06 COPEDEC VII, 2008, Dubai, UAE.

Primavera, J.H. (2006) Overcoming the Impacts of Aquaculture on the Coastal Zone. Ocean \& Coastal Management, Vol. 49: 531-545.

Ranasinghe, T. (2010) Sustainable Financing and Benefit- Sharing Strategy for Conservation and Management of Puttalam Lagoon. For the Project: Ecologically and Socio Economically Sound Coastal Ecosystem Rehabilitation and Conservation in Tsunami Affected Countries of the Indian Ocean - Sri Lanka Component.

Ruiz-Velazco, J.M.J., A. Hernandez-Llamas, V.M. Gomez-Munoz and F.J. Magallon, (2010) Dynamics of Intensive Production of Shrimp Litopenaeus vannamei Affected by White Spot Disease. Aquaculture, Vol. 300(1-4): 113-119.

Satyanarayana, B., S. Mulder, L.P. Jayatissa, F. Dahdouh-Guebas (2013) Are the Mangroves in the GalleUnawatuna Area (Sri Lanka) at risk? A Social-ecological Approach Involving Local Stakeholders for a Better Conservation Policy. Ocean \& Coastal Management, Vol. 71: 225237.

Senarath, U. and C. Visvanathan (2001) Environmental Issues in Brackish Water Shrimp Aquaculture in Sri Lanka. Environmental Management, Vol. 27(3): 335-348.

Silva, E. I. L., J. Katupotha, O. Amarasinghe, H. Manthrithilake and R. Ariyaratna (2013) Lagoons of Sri Lanka: from the origins to the present. Colombo, Sri Lanka: International Water Management Institute (IWMI), 122p.

Stevenson, N. J. (1997) Disused Shrimp Ponds: Options for Development of Mangrove. Coastal Management, Vol. 25(4): 425-435.

Tanavud, C., O. Densrisereekul and T. Sansena (2010) Reclamation of Land Disturbed by Shrimp Farming in Songkla Lake Basin, Southern Thailand. Land Degradation and Desertification: Assessment, Mitigation, Remediation, pp. 355-362.

Tejedor, E. Diaz. (2013) Evaluation of the Existing Status of Shrimp Farms in Puttalam District, Sri Lanka, with Regards to their Environmental Condition and Current Management Practices and Recommendations of the Routes to Achieve Climate Compatible Development (CCD). Honours Thesis, School of Life, Sport and Social Sciences, Edinburgh Napier University.

Tendencia, E.A. and J.A.J. Verreth (2010) Temperature Fluctuation, Low Salinity, Water Microflora: Risk Factors for WSSV Outbreaks in Penaeus monodon. The Israeli Journal of Aquaculture, Vol. 63: 548-555. 
Tho, N., N. Vromat, N.T. Hung, and L. Hens (2008) Soil Salinity and Sodicity in a Shrimp Farming Coastal Area of the Mekong Delta, Vietnam. Environmental Geology, Vol. 54(8): 1739-1746.

Travers, A., C. Elrick, R. Kay and O. Vestergaard (2012) Ecosystem-based Adaptation Guidance. Moving from Principles to Action. Working Document. UNEP Division of Environment Policy Implementation.

Twilley, R. R., R.H. Chen and T. Hargis (1992) Carbon Sinks in Mangroves and their Implications to Carbon Budget of Tropical Coastal Ecosystems. Water Air Soil Pollut, Vol. 64: 265-288.

UNDP-UNEP (2011) Mainstreaming Climate Change Adaptation into Development Planning: A Guide for Practitioners. United Nations Development Programme (UNDP) - United Nations Environment Programme (UNEP). Available online at: www.unpei.org.

Vanpatten, K.A., L.M. Nunan and D.V. Lightner (2004) Seabirds as Potential Vectors of Penaeid Shrimp Viruses and the Development of a Surrogate Laboratory Model Utilizing Domestic Chickens. Aquaculture, Vol. 241: 31-46.

Vargas-Albores, F., P. Inojosa-Baltazar, G. Portillo-Clark and F. Margallon-Varajas (1998) Influence of Temperature and Salinity on the yellowleg shrimp, Penaeus californieinsis Holmes, Prophenoloxidase system. Aquaculture Research, Vol. 29: 549-553.

Witteveldt, J., C. Cifuentes, J.M. Vlak and M.C.W. van Hulten (2004) Protection of Penaeus monodon against White Spot Syndrome Virus by Oral Vaccination. Journal of Virology, Vol. 78(4):20572061.

WWF (2011) Draft Standards for Responsible Shrimp Aquaculture. Created by the Shrimp Aquaculture Dialogue December 2011, Version 3.0 for Guidance Development and Field Testing.

WWF (2014) Overview Shrimp Farming. http://worldwildlife.org/industries/farmed-shrimp. (Accessed 1 May 2014).

\section{Glossary}

\begin{tabular}{|l|l|}
\hline ABW & Average Body Weight \\
\hline ASC & Aquaculture Stewardship Council \\
\hline ASP & Active Suspension Pond \\
\hline BAP & Best Aquaculture Practices \\
\hline BAU & Business As Usual \\
\hline BMP & Better Management Practices \\
\hline BOI & Board of Investment \\
\hline CC\&CRMD & Coast Conservation and Coastal Resources Management Department \\
\hline CCD & Climate Compatible Development \\
\hline CDKN & Climate and Development Knowledge Network \\
\hline CEA & Central Environmental Authority \\
\hline DDS & District Divisional Secretariat \\
\hline DFAR & Department of Fisheries and Aquatic Resources \\
\hline DFC & Department of Forest Conservation \\
\hline DFID & Department For International Development \\
\hline DWC & Department of Wildlife Conservation \\
\hline GHG & Green House Gasses \\
\hline NAQDA & National Aquaculture Development Authority \\
\hline NARA & National Aquatic Resources Research and Development Agency \\
\hline
\end{tabular}




\begin{tabular}{|l|l|}
\hline NSAP & National Strategy Action Plan \\
\hline NTFP & Non-Timber Forest Products \\
\hline NWP & North Western Province \\
\hline PES & Payment for Ecosystem Services \\
\hline PL & Post Larvae \\
\hline PLCMP & Puttalam Lagoon Conservation Management Plan \\
\hline RAS & Recirculating Aquaculture System \\
\hline SAM & Special Area Management \\
\hline SD & Secretariat Division \\
\hline TEV & Total Economic Value \\
\hline UDA & Urban Development Authority \\
\hline UNDP & United Nations Development Programme \\
\hline UNEP & United Nations Environment Programme \\
\hline UNFCCC & United Nations Framework Convention on Climate Change \\
\hline WSSV & White Spot Syndrome Virus \\
\hline
\end{tabular}

\section{Highlights}

- An estimated $90 \%$ of the shrimp ponds along the coast of Puttalam Lagoon lay barren.

- These deserted shrimp farms are unsuitable for agricultural purposes.

- Development goals and EU demand provide strong incentives for shrimp farming.

- New approaches are required to produce shrimp in a sustainable way.

- Mechanisms have been identified to support Climate Compatible Development. 